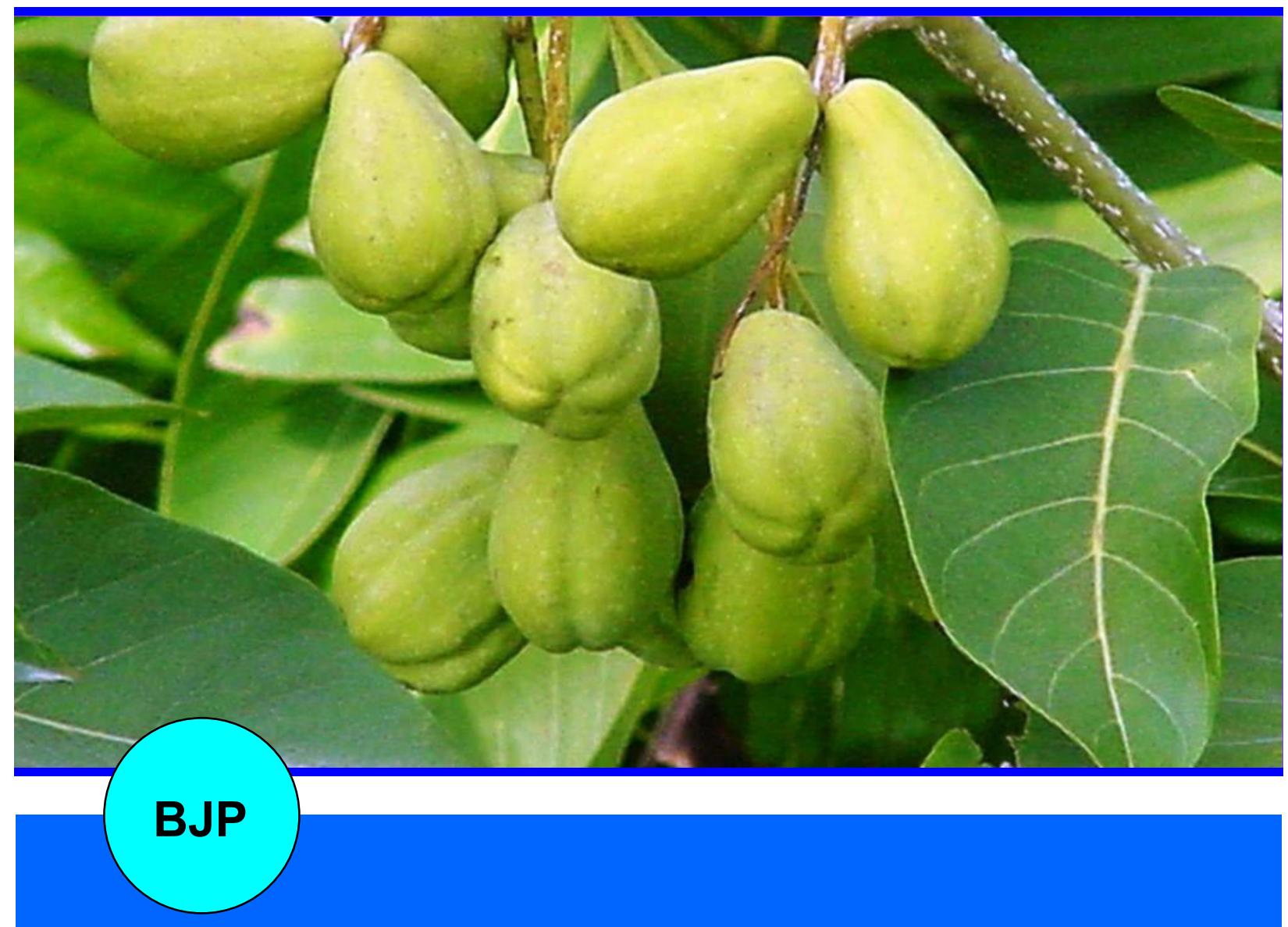

Bangladesh Journal of Pharmacology

Research Article

Anti-colon cancer activity of endophytic fungal strains from Terminalia chebula Rezt 
Abstracted/indexed in Academic Search Complete, Asia Journals Online, Bangladesh Journals Online, Biological Abstracts, BIOSIS Previews, CAB Abstracts, Current Abstracts, Directory of Open Access Journals, EMBASE/Excerpta Medica, Google Scholar, HINARI (WHO), International Pharmaceutical Abstracts, Open J-gate, Science Citation Index Expanded, SCOPUS and Social Sciences Citation Index;

ISSN: $1991-0088$

\title{
Anti-colon cancer activity of endophytic fungal strains from Terminalia chebula Rezt
}

\author{
Mohammad Shoeb, Paul Kong Thoo-Lin, and Nilufar Nahari \\ ${ }^{1}$ Department of Chemistry, University of Dhaka, Dhaka 1000, Bangladesh; ${ }^{2}$ School of Pharmacy and Life Science, \\ The Robert Gordon University, Aberdeen AB25, $1 \mathrm{HG}$, UK.
}

\begin{tabular}{|c|c|}
\hline \multicolumn{2}{|l|}{ Article Info } \\
\hline & \\
\hline & \\
\hline Available Online: & \\
\hline \multicolumn{2}{|c|}{ DOI: 10.3329/bjp.v7i1.10507 } \\
\hline \multicolumn{2}{|c|}{$\begin{array}{l}\text { Cite this article: } \\
\text { Shoeb M, Thoo-Lin PK, Nahar N. Ant } \\
\text {-colon cancer activity of endophyti } \\
\text { fungal strains from Terminalia chebul } \\
\text { Rezt Bangladesh J Pharmacol. 2012; } 7 \\
\text { 47-49. }\end{array}$} \\
\hline
\end{tabular}

\begin{abstract}
Endophytic microorganisms are fungi or bacteria that live inside the healthy tissues of the host plants causing no apparent symptoms of diseases. Five endophytic fungal strains labeled as IR-1, IR-2, IR-4, IR-6 and IR-7 (identified as Penicillium thiomii) were isolated from the medicinal plant of Terminalia chebula Retz by culture and sub-culture. The ethyl acetate extract of fungal strains, IR-4, IR-6 and IR-7 inhibited the growth of CaCo- 2 colon cancer cell lines in MTT assay with $\mathrm{IC}_{50}$ values of 55,44 and $67 \mu \mathrm{g} / \mathrm{mL}$ respectively.
\end{abstract}

\section{Introduction}

The word endophyte means inside the plant and refers to microorganisms, i.e. fungi and bacteria that spend the whole or parts of their life cycle colonizing inter or intra-cellularly inside the healthy tissues of the host plants, typically causing no apparent symptoms of diseases (Petrini, 1991). Endophytic fungi have been shown to produce pharmaceutically important plant metabolites, with the most prominent example being paclitaxel, better known as taxol. Taxol was originally isolated from the bark of the Pacific yew tree Taxus brevifolia (Strobel et al., 2004). Later, it was discovered that the fungal endophyte Taxomyces andreanae, associated with this tree, also produces taxol upon fermentation (Stierie and Strobel, 2003). This example illustrates the biotechnological potential of endophytic fungi, since unlike their plant hosts they are amenable to fermentation, which could represent a sustainable source for unlimited supply of natural products. Endophytic fungi also are a highly diverse source of new chemical entities on their own right, with almost 300 new natural products being reported between 1987 and 2006 (Tan and Zou, 2001; Zhang et al., 2006).. Thus, endophytic microorganisms are a rich source of bioactive compounds with a great potential to discover new lead structures for drug discovery. The bioactive strains are possible to cultivate in large scale by fermentation to isolate the active compound(s) in larger amount rather than destroying natural plant resources. Terminalia chebula Retz (Haritaki) is one of the important medicinal plants of Bangladesh. As a part of our ongoing research on endophytic fungi, two new compounds terminatol and 4, 7-dimethyl-1,3-dioxacyclohepta-2-one and several known secondary metabolites were isolated from endophytes of T. chebula earlier (Rob et al., 2005; Shoeb et al., 2010). We, now report the in vitro anti-colon cancer activity of the extracts of fungal strains from T. chebula.

\section{Materials and Methods \\ Plant collection and sterilization}

The medicinal plant, Terminalia chebula Retz, locally known as Haritaki was collected from a nursery of Dhaka city. Different parts (leaves, stems and roots) of 
the plant were cut into small pieces. Each plant part was surface sterilized with $70 \%$ ethanol, 3\% sodium hypochlorite and sterile water (Schulz et al., 1983). The agar media was autoclaved at $120^{\circ} \mathrm{C}$ at 1 atmosphere pressure for $30 \mathrm{~min}$.

\section{Isolation of endophytic fungi}

The surface sterilized plant materials were inoculated on autoclaved potato dextrose agar media on a sterilized petridish (90 $\mathrm{mm}$ in diameter) and after 21 days, twenty one fungal strains were isolated for identification. By dereplication of common fungi, five strains labeled as IR-1, IR-2, IR-4, IR-6 and IR-7 were found to have optimum growth for further cultivation. IR-7 was identified as Penicillium thiomii by Prof. Barabara Shultz, Technical University of Braunschweig, Germany. The fungal strains IR-4, IR-6 and IR-7 were selected for cytotoxic studies.

\section{Culture and extraction}

The fungal strains IR-4, IR-6 and IR-7 were separately fermented in a large scale (450 Petri dishes of $90 \mathrm{~mm}$ in diameter) in the potato dextrose agar semi solid medium at $\sim 22-25^{\circ} \mathrm{C}$. After 21 days the fungi were collected in a round bottom flask and the content was freeze-dried. The dried powdered material was extracted with ethyl acetate $(3 \times 1500 \mathrm{~mL}$ for 24 hours, at room temperature). The ethyl acetate extract was evaporated to dryness. A small part of dried materials from IR-6 was also extracted with 70\% ethanol.

\section{Cryopreservation of cancer cells}

CaCo-2, human colon cancer cell line was obtained from the European collection of cell cultures. Cells were cryopreserved to ensure the continuous supply of a cell line during this study. Healthy and viable cells $4-10 x$ 106 per ampoule were used for this purpose. Freezing medium was prepared from the growth medium containing $10 \%$ (v/v) sterile dimethyl sulphoxide. Cell pellets dissolved in $1 \mathrm{~mL}$ freezing medium were poured into a sterile plastic screw-top cryotubes and immediately cooled at a rate of between $1-5^{\circ} \mathrm{C}$ per min. Normally the cryotubes were placed in the $-20^{\circ} \mathrm{C}$ freezer for 3-4 hours and transferred to the $-80^{\circ} \mathrm{C}$ for approximately 16 hours (overnight). After freezing, the ampoules were preserved in liquid nitrogen.

\section{Thawing of frozen cells}

The ampoule was removed from storage and unscrewed the cap $1 / 4$ turn to release any residual nitrogen. After 1-2 min (to let gas escape) it was placed in the water bath at $37^{\circ} \mathrm{C}$. Special care was taken in order to prevent water entering the ampoule and contaminating the cells. When ampoules were fully thawed, they were taken to the laminar flow hood. Then contents of ampoule were transferred into a $30 \mathrm{~mL}$ sterile universal bottle. The growth medium $(10 \mathrm{~mL})$ was added slowly to the universal bottle, shaken slowly and centrifuged. After decanting the supernatant, the pelleted cells were resuspended in fresh Earle's minimum essential medium and transferred to a culture flask.

\section{Cell counting}

Cells were counted by haemocytometer and particle size distributor. Similar results were obtained in both cases and constant cell density was maintained for all cell culture work in this study.

\section{Cell viability assay}

CaCo-2 cells were maintained in Earle's minimum essential medium, supplemented with $10 \%(\mathrm{v} / \mathrm{v})$ foetal calf serum, $2 \mathrm{mM}$ L-glutamine, $1 \% \quad(\mathrm{v} / \mathrm{v})$ non-essential amino acids, $100 \mathrm{IU} / \mathrm{mL}$ penicillin and $100 \mathrm{~m} \mathrm{~g} / \mathrm{mL}$ streptomycin. Exponentially growing cells were seeded on 96-well plates at $1 \times 104$ cells per well and incubated for 24 hours before the addition of extracts. Stock solution of samples was initially dissolved in DMSO and further diluted with serum free medium. Following a 24 hours incubation at $37^{\circ} \mathrm{C}, 5 \% \mathrm{CO}_{2}, 100 \mathrm{~mL}$ of various concentration of test extracts $(100,80,40,20,4$, $0.4,0.04$ and $0.004 \mathrm{~m} \mathrm{~g} / \mathrm{mL}$ ) were added in each well in triplicates and cells were further incubated for 72 hours (Mosmann, 1983). After 72 hours of incubation at $37^{\circ} \mathrm{C}$, the medium was removed, and $100 \mathrm{~mL}$ of MTT reagent $(1 \mathrm{mg} / \mathrm{mL})$ in serum free medium was added to each well. The plates were incubated at $37^{\circ} \mathrm{C}$ for 4 hours. At the end of the incubation period, the supernatants were removed and, pure DMSO $(200 \mathrm{~mL})$ was added to each well and plates were shaken gently for $15 \mathrm{~min}$. The metabolized MTT product dissolved in DMSO was quantified by reading the absorbance at $560 \mathrm{~nm}$ using a micro plate reader (Dynex Technologies, USA,). $\mathrm{IC}_{50}$ values are calculated from the equation of the logarithmic line determined by fitting the best line (Microsoft Excel) to the curve formed from the data. The $\mathrm{IC}_{50}$ value was obtained from the equation $\mathrm{y}=50$ (50\% value).

\section{Results and Discussion}

The fungal strains, IR-4, IR-6 and IR-7 were tested in MTT cytotoxicity assay (Mosmann, 1983) using the CaCo-2 colon cancer cell lines for possible cytotoxic activities. The MTT assay is a well-documented cell viability assay and has been modified by several investigators since it was first developed by Mosmann (Mosmann, 1983; Monks et al., 1991). This assay is based on the transformation of tetrazolium salt, 3-[4,5dimethylthiazol-2-yl]-2,5-diphenyl tetrazolium bromide (MTT) by mitochondrial succinic dehydrogenases in viable cells yielding purple formazan crystals that are not soluble in aqueous solution. The amount of formazan generated by dehydrogenase enzyme is 
Table I

MTT cytotoxicity assay of extracts of endophytic fungi from $T$. chebula

\begin{tabular}{lc|}
\hline Extracts & Cytotoxicity $(\mu \mathrm{g} / \mathrm{mL})$ \\
\hline Ethyl acetate extract of IR-4 & 55 \\
Ethyl acetate extract of IR-6 & 44 \\
Ethyl acetate extract of IR-7 & 67 \\
Ethanol extract of IR-6 & 71 \\
\hline
\end{tabular}

directly proportional to the number of viable cells in culture and is measured at $560 \mathrm{~nm}$. The ethyl acetate extracts of fungal strains IR-4, IR-6, IR-7 and ethanol extract of IR-6 showed significant cytotoxic activities with $\mathrm{IC}_{50}$ values of $55,44,67$ and $71 \mathrm{mg} / \mathrm{mL}$, respectively (Table I). As crude extract may contain several compounds, further work is necessary to isolate the active principles for the cytotoxicity of these extracts. The isolation of endophytic fungi from medicinal plants and their study for bioactive secondary metabolites by fermentation in large scale can produce potential drug candidates and help to conserve the biodiversity of medicinal plants in the country. This is the first report on the assessment of the extracts of these fungal strains for their cytotoxicity towards the $\mathrm{CaCo}-2$ in vitro colon cancer cell line.

\section{Acknowledgement}

The authors are grateful to International Foundation for Sciences (IFS), Sweden and Organization for the Prohibition for Chemical Weapons (OPCW), The Netherlands for financial supports.

\section{References}

Monks A, Scudiero D, Skehan P, Shoemaker R, Paull K, Vistica D, Hose C, Langley J, Cronise P, Vaigro-Wolff A, GrayGoodrich M, Campbell H, Mayo J, Boyd M. Feasibility of a high-flux anti-cancer drug screen using a diverse panel of cultured human tumor cell lines. J Natl Cancer Inst. 1991; 83: 757-66.

Mosmann T, Rapid colorimetric assay for the cellular growth and survival: Application to proliferation and cytotoxicity assays. J Immunol Methods. 1983; 65: 55-63.

Petrini O. Fungal endophytes of tree leaves. In: Microbial Ecology of leaves. New York, Springer- Verlag, 1991, p 179.

Rob T, Rahman MR, Mosihuzzaman M, Rahman KM, Sultana N. J Bangladesh Chem Soc. 2005; 18: 64-69.

Schulz B, Wanke U, Drager S, Aust HJ. Endopytes from herbaceous plants and shrubs: Effectiveness of surface sterilization methods. Mycological Res. 1983; 65: 1447-50.

Shoeb M, Begum S, Mamun MIR, Nahar N. Chemical and biological activity studies of endophytic fungus from Terminali chebula Rezt. J Bangladesh Chem Soc. 2010; 23: 10107.

Stierie A, Strobel GA. Taxol and taxane production by Taxomyces ancireanae. Science 2003; 260: 214-16.

Strobel G, Daisy B, Castillo U, Harper J. Natural products from endophytic microorganisms. J Nat Prod. 2004; 67: 257-68.

Tan RX, Zou WX, Endophytes: A rich source of functional metabolites. Nat Prod Rep. 2001; 18: 448-59.

Zhang HW, Song YC, Tan RX. Biology and chemistry of endophytes. Nat Prod Rep. 2006; 23: 753-71.

\section{Author Info \\ Mohammad Shoeb (Principal contact) \\ I e-mail: shoeb71@yahoo.com}

